\title{
Trends in Courier Services in Terms of Digitalization of Commerce
}

\author{
Chief Ass. Prof. PhD Elitsa Gramatikova \\ University of Economics - Varna, Varna, Bulgaria \\ e_gramatikova@ue-varna.bg
}

\begin{abstract}
The modern commerce is changing dynamically under the influence of information innovations and the gradual transition of existing economic and social systems into the digital age. Merchants are using the digital technologies to make it easier for consumers to shop and explore their behavior, expectations and preferences. However, this development requires a quick adaptation of courier services to suit customer preferences. This paper examines changes in the logistics industry and supply chain due to the development of artificial intelligence (AI), the growing role of Internet of Things (IoT) in the delivery industry, the autonomous vehicle management, the use of $3 D$ printing for custom production and other current trends to accelerate delivery time and customer satisfaction.
\end{abstract}

Keywords: digitalization, modern commerce, courier services, customer satisfaction, artificial intelligence

JEL Code: L81, L87; doi:10.36997/IJUSV-ESS/2019.8.3.17

\section{Въведение}

Търговската индустрия през последните години все повече се трансформира с навлизане на дигитализацията, в отговор на потребителските желания и нагласи. Тази трансформация се наблюдава в световен мащаб и представлява адаптация към изменящите се потребителски навици. Все повече търговци използват дигиталните технологии, за да улесняват потребителите при пазаруването и да проучват тяхното поведение, очаквания и предпочитания. Развитието на омниканалната търговия обаче е невъзможно без развитието на куриерските услуги, тъй като независимо от предлаганото разнообразие от търговски канали, по които потребителите да стигнат до покупка, стоките трябва да се придвижат до купувачите. Голяма част от потребителите предпочитат електронно закупените от тях стоки да бъдат доставени директно до дома им или до друго удобно за тях място, а това изисква предлагане на подходяща куриерска услуга. За дигиталните потребители възможността за удобна доставка и евентуално връщане на стоката представлява повратен момент в онлайн пазаруването. Електронното пазаруване и доставката на стоките са неразделна част от общото потребителско преживяване, поради което в интерес на търговците е да оставят дълготрайно положително впечатление от пазаруването. Това налага активното използване на всички иновации, които могат да предложат куриерските фирми.

Целта на статията е да разкрие последните тенденции в куриерските услуги, подпомагащи търговската индустрия при нейната дигитализация и осигуряващи нови бизнес модели, ориентирани към клиента; оперативна ефективност и по-удовлетворяващи потребителски преживявания. \section{8 г.}

\section{1. Демографските показатели и онлайн продажбите в Европа и България през}

Населението на европейския континент продължава да нараства и през 2019 г. се очаква да достигне 798,4 млн. души. В сравнение през 2013 г. в Европа са живели 784,9 млн. души или за 6 години увеличението на населението е $1,72 \%$. Най-голямата част от населението е концентрирана в Западна Европа - почти 249 млн. души, след което се нарежда Източна Европа - с малко над 225 млн. души; Южна Европа - с 215,6 млн. души и Централна Европа - 75,7 млн. души. Най-малка е концентрацията на населението в Северна Европа - само 33,2 млн. души. По възрастова структура най-голяма е групата на населението, 
попадащо в диапазона „25-54 години“ - 42,23\%, следвана от групата „над 65 години“ $17,08 \%$, а най-малобройна е групата на населението в диапазона „15-24 години“ - 11,01\%. В Западна и Северна Европа живеят най-много възрастни хора над 65 години, съответно $19,89 \%$ и $19,18 \%$.

Северна Европа има най-високото ниво на навлизане на интернет сред населението 93,3\%, докато в Източа Европа навлизането е все още само 71\%. От 34 европейски държави най-високо ниво на проникване на интернет сред населението през 2018 г. се наблюдава в Исландия - 99\%, а най-ниско в Украйна - 64\%. България се нарежда на предпоследно място в класацията със 67\% на интернет покритие сред населението. Тези различия между отделните държави не са изненадващи, а резултат на много по-ниския жизнен стандарт на населението в Източна Европа спрямо населението в Северна и Западна Европа, като се очаква до няколко години интернет проникването значително да се подобри.

Най-голям процент потребители, които са използвали интернет за осъществяване на покупки през 2018 г. са отчетени в Швейцария - 88\%, следвана от Великобритания - 87\% и Дания - 86\%, а най-малко потребители, пазарували онлайн, са отчетени в Украйна - 22\%, Румъния - 26\%, България и Северна Македония с по 31\%. По-голямата част от оборота от електронната търговия се осъществява в Западна Европа и съставлява 66\% от общия оборот. Средно процентът на онлайн пазаруващите в тази част на Европа възлиза на 81,4\%, а средната стойност на годишните покупки - 1968 евро. Тази средна стойност включва 10,5\% ръст на онлайн покупките спрямо предходната година. В Северна Европа се наблюдава найвисока стойност на онлайн покупките през 2018 г., падащи се на един потребител - 2045 евро. Тук са отчетени 77\% онлайн потребители и 5,4\% среден ръст на стойността на електронните покупки спрямо предходната година. В Източна Европа 52\% от населението са осъществили електронна покупка, а средната стойност на годишните онлайн покупки възлиза на 276 евро или около 7,4 пъти по-ниска стойност в сравнение с потребителите в Северна Европа и 7,1 пьти по-ниска стойност в сравнение с потребителите в Западна Европа. Средният ръст на стойността на онлайн покупките в Източна Европа за 2018 г. е 5\%. Потребителите в Малта, Кипър, Люксембург и Австрия са осъществили най-много покупки от европейски търговци, извън своята страна (81-89\%), докато потребителите от Турция, Сърбия и Полша са осъществили най-малко такива (7-12\%). В България 35\% от онлайн покупките са били осъществени от търговци от други европейски страни и $17 \%$ от търговци извън Европа. Тези данни показват значителни различия между отделните европейски държави в нивата на онлайн пазаруването, но същевременно разкриват голяма по обем потенциална аудитория, с която да се увеличи онлайн потреблението в бъдеще.

По данни на European E-commerce Report (European Ecommerce 2018) около 30\% от онлайн закупените стоки от европейските потребители са били върнати, като 92\% от потребителите биха купили отново от същия електронен магазин, при положение че условията за връщане на стоките са лесни и бързи за изпълнение. Между държавите в Европа има големи различия в локалната логистична инфраструктура и възможните начини на доставка и плащане на стоките, което се отразява на потребителското удовлетворение и желанието за нови онлайн покупки. От значение са и допълнителните разходи за доставка, които много често са причина потребителите да откажат поръчка на финалния етап от нейното потвърждаване (Lazar 2019). Изводът от тези проучвания е, че при онлайн търговията един от най-важните компоненти е именно доставката. Потребителите търсят инструменти за проследяване на пратката, особено когато поръчват стоки от други страни и те трябва да преминат няколко граници. Предлагането на лесни и ясни за изпълнение условия за връщане или проследяване на закупените стоки улесняват потребителите при вземането на решение за онлайн покупка. 
По данни на доклад (European Ecommerce 2019), изготвен от еCommerce Europe и EuroCommerce $^{1}$ през 2019 г. се очаква секторьт на елекронната тьрговия в Европа да продължи да нараства с бързи темпове и да достигне в края на годината 621 млрд. евро. Този обем представлява $13 \%$ ръст на европейския оборот от електронна търговия по модела „бизнес - клиенти“ спрямо предходната 2018 година. Само за България електронните продажби през 2018 г. са нарастнали с 30\% спрямо 2017 г. Важно е да се отбележи, че Българската асоциация за електронна търговия има сериозни опасения относно "Наредба № Н-18 от 13 декември 2006 г. за регистриране и отчитане чрез фискални устройства на продажбите в търговските обекти, изискванията към софтуерите за управлението им и изисквания към лицата, които извършват продажби чрез електронен магазин". Според асоциацията тази наредба не съответства на стратегията за единен европейски цифров пазар и създава бариери пред българските дигитални компании, тъй като към електронните магазини се прилагат изисквания, които са разработени за физически тьрговски обекти, а това създава проблеми, несигурност и неяснота сред представителите на електронния бизнес и потребителите. В резултат на изискванията на наредбата българските фирми, занимаващи се с електронната търговия, са поставени в по-неблагоприятна позиция спрямо техните международни конкуренти.

\section{2. Нивото на дигитализация в България}

Според доклад на Европейската комисия относно индекса за навлизането на цифровите технологии в икономиката и обществото - DESI (European Commission 2019) през 2018 г. България се нарежда на 26-то място сред 28 държави-членки на Европейския съюз. България е запазила позицията си от 2017 г. с леки подобрения на резултатите. Страната ни е отбелязала напредък по отношение на свързаността и предоставянето на цифрови услуги, и по-специално - цифровите обществени услуги, което е довело до увеличен брой потребители на услуги на електронното управление. Основните проблеми произтичат от ниското ниво на умения у населението в областта на цифровите технологии, недостига на специалисти по ИКТ, ниското равнище на въвеждане на цифровите технологии в стопанската дейност и недостатъчните инвестиции в цифрова инфраструктура.

Въпреки, че България е разработила редица стратегии и програми, като: „Национална стратегия за развитие на широколентовия достъп в Република България (2012-2015)“ (Ministerstvo na transporta, informatsionnite tehnologii i saobshteniyata 2012); „Стратегия за участието на България в четвъртата индустриална революция (Индустрия 4.0)“ (Bulgarian Industrial Association 2018); „Концепция за цифрова трансформация на българската индустрия (Индустрия 4.0)“ (Ministerstvo na ikonomikata 2017); „Стратегия за ефективно прилагане на информационни и комуникационни технологии в образованието и науката на Република България (2014-2020 г.)“ (Ministerstvo na obrazovanieto i naukata 2014); „План за реализация на Стратегията за ефективно внедряване на ИКТ в образованието и науката (2014-2020 г.)“ (Ministerstvo na obrazovanieto i naukata 2014) и „Стратегия за развитие на електронното управление в Република България 2014 - 2020 г.“ (Ministerstvo na transporta, informatsionnite tehnologii i saobshteniyata 2014), страната ни все още се отнася в групата на държавите със слаби резултати ${ }^{2}$.

\footnotetext{
${ }^{1}$ EuroCommerce е основната европейска организация, представляваща сектора на търговията на дребно и едро. Тя обхваща национални асоциации в 31 страни и 5,4 млн. компании, които са както водещи търговски предприятия (Carrefour, Ikea, Metro и Tesco), така и много малки предприятия.

${ }^{2}$ Страни със слаби резултати по индекса DESI: България, Гърция, Италия, Кипър, Полша, Румъния, Словакия, Унгария, Хърватия.
} 

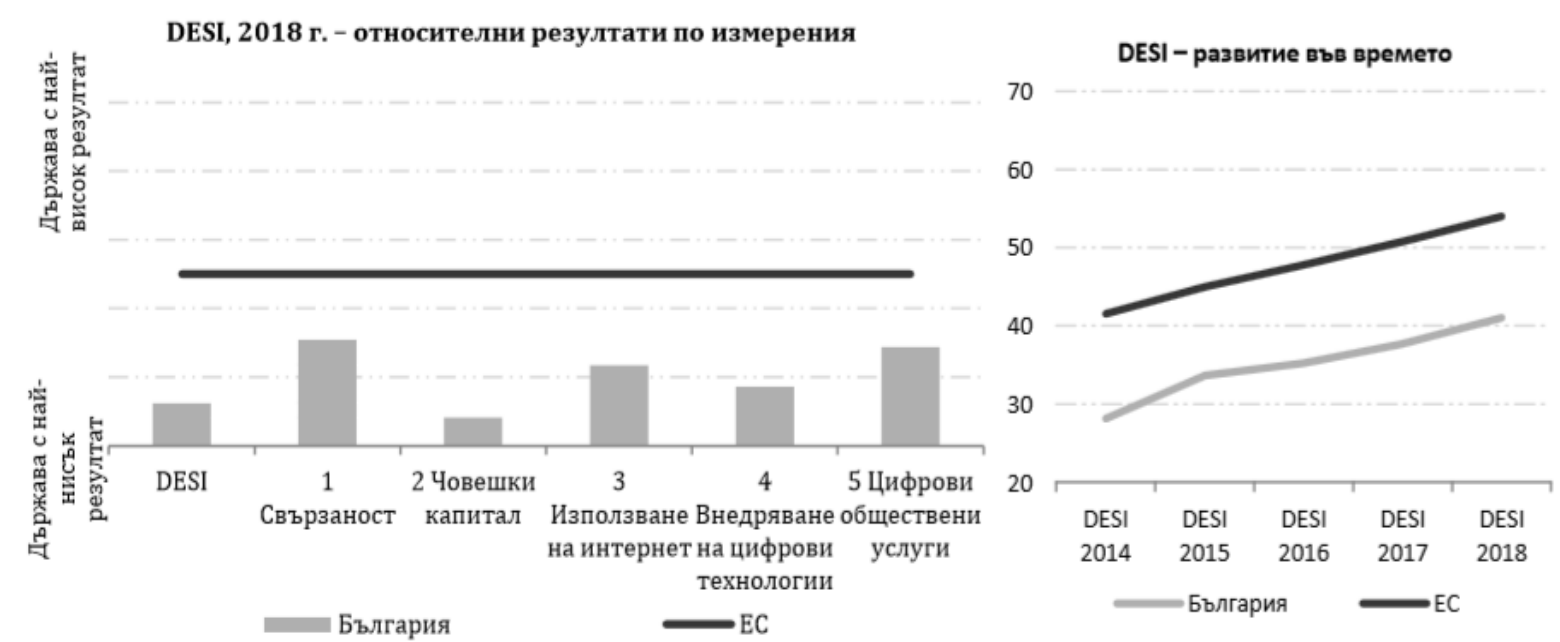

Фигура 1. Позиция на България сред страните в EC по индекса DESI за 2018 г. (European Commission 2019)

По отношение на измерването „свързаност“ България слиза от 23 място през 2017 г. на 25 място през 2018 г. Общото покритие на страната с фиксирани широколентови мрежи обхваща 95\% от домакинствата, при средното ниво за ЕС - 97\%. Разпространението на фиксиран широколентов достьп до интернет е достигнало 59\% от домакинствата в страната, но е значително под средното ниво за ЕС от 75\%. България изостава и спрямо покритието с мрежи 4G - 72\% от домакинствата при средно покритие за ЕС - 91\% от домакинствата. Близки до средното европейско ниво са стойностите при разпространението на мобилния широколентов достъп до интернет - 87\%, при средно ниво за ЕС от 90\%. Въпреки слабото увеличение спрямо 2017 г. по повечето показатели относно свързаността, България се развива по-бавно от останалите държави от ЕС, а това забавя развитието на цифровата икономика и общество.

Друга група измервания са свързани с човешкия капитал. Тук България отново отбелязва слаб напредък и запазва позицията си от 2017 г. - предпоследно 27 място. Голям недостатьк е ниското ниво на общото равнище на уменията в областта на цифровите технологии. Налице е $3 \%$ увеличение спрямо предходната година на броя на лицата с поне основни умения в областта на цифровите технологии (общо 29\% през 2018 г.) и 4\% увеличение на броя на лицата, които използват интернет (общо 62\% през 2018 г.). Независимо от отчетеното увеличение, България остава сред държавите с най-ниски резултати, тъй като средната стойност за ЕС на лицата с поне основни умения в областта на цифровите технологии достига 57\%, а потребителите на интернет съставляват $81 \%$. Страната ни изостава и по брой дипломирани специалисти в областта на точните науки, технологиите, инженерството и математиката - 13,9\% спрямо 19,1\% средно за ЕС през 2018 г.

Не са изненадващи и резултатите относно използването на интернет, където запазваме 26 място от предходната година. Българските граждани използват интернет предимно за телефонни и видеоразговори, като това е най-високата стойност в ЕС. Изследването показва, че $85 \%$ от българите, използвали интернет през последните три месеца, са осьществявали телефонни или видеоразговори при средна стойност за ЕС само 46\%. Високи са показателите и за нивото на използване на социални мрежи - 79\% при средна стойност за ЕС - $65 \%$. В същото време българските потребители не използват пълноценно потенциала на електронната тьрговия и през 2017 г. само 27\% от българските интернет потребители са пазарували по интернет, при среден дял за ЕС от 68\%. Много нисък е и броят на лицата, които са използвали интернет банкиране - само 9\% от всички интернет потребители, при 
средна стойност $61 \%$ за ЕС.

България запазва 26 място в класацията на DESI за 2018 г. и по отношение внедряването на цифрови технологии, чието възприемане от страна на предприятията става сравнително бавно. Налице са недостатъчни инвестиции за цифровизация на икономиката и недостиг на специалисти по ИКТ, които води до изоставане на България в сравнение с другите държави-членки на ЕС. Така например дельт на МСП, които осъществяват онлайн продажби, през 2017 г. е само 7,1\% при средно ниво за ЕС от 17,2\%. Предприятията, споделящи електронно информация, са само $23 \%$ при средно ниво за ЕС от $34 \%$, а трансграничните онлайн продажби от МСП са 3,4\% при средна стойност за ЕС от 8,4\%.

Последната група измервания в индекса DESI обхващат цифровите обществени услуги. Тук България се нарежда на 23 място през 2018 г., тъй като бяха предприети мерки за подобряване на тези услуги и програма за цифровизация на държавната администрация. Към момента броят на българските потребители на услуги на електронното управление съвпада със средното за ЕС - 58\%. Наложително е ускореното развиване на услугите за електронно здравеопазване, тъй като България остава под средното ниво за ЕС.

Онлайн проучване за нивото на цифровизация в България е проведено от $\mathrm{Siemens}^{3}$ в партньорство с Германо-Българската индустриално-тьрговска камара (ГБИТК) в периода от края на май до края на юни 2018 г., като в него са включени мениджъри от 76 компании, работещи в 33 бизнес сектори (АНК Bulgarien 2018). Проучването си е поставило няколко цели:

$\checkmark$ Да посочи аспектите на цифровизацията, които са ключови за участниците в проучването, както и наличието на пречки и бариери, свързани с внедряването на новите дигитални технологии;

$\checkmark$ Да проучи наличието на разработени дигитални стратегии от участниците и етапите във връзка с тяхното внедряване;

$\checkmark$ Да изясни нивото на дигитализация в България и очакванията на бизнеса по отношение на ефектите от дигиталната трансформация на икономиката.

$71 \%$ от компаниите, участвали в анкетата, са представители на средни и малки предприятия (11-500 служители), 17\% са представителите на микро предприятията (1-10 служители) и $12 \%$ попадат в категорията на големите предприятия с над 500 служители. Обхванатите браншове включват химическа промишленост, търговия, машиностроене, енергетика, строителство, туризъм, ИТ сектор, транспорт и др., като целта е широкото представяне на различните браншове да даде пълна картина на състоянието и очакванията на българския бизнес по отношение внедряването на цифровите технологии.

Най-важните аспекти на цифровизацията от основно значение за изследваните компании се явяват автоматизацията на производството и оптимизацията на ресурсите - при $59 \%$ от анкетираните мениджьри, следвани от интеграцията на дигиталните процеси - при $55 \%$, подобреното взаимодействие с крайните клиенти - при 53\% и свързаността - при $51 \%$. Малко повече от половината анкетирани - 53\% смятат, че внедряването на "интелигентни" среди (например „умни“ градове и „умни“ фабрики), заедно със свързаността и „Интернет на нещата“" (свързването на хора, машини и продукти) са най-важните тенденции на дигиталната трансформация.

Проучването разкрива, че само $5 \%$ от изследваните предприятия са разработили дългосрочна дигитална стратегия, надхвърляща период от 10 години. Според мениджърите дигитализацията може да доведе до значими преимущества, само когато се основава на

\footnotetext{
3 Siemens AG е световен лидер в производството на иновативни решения в сферата на електрификацията, автоматизацията и дигитализацията.
} 
дългосрочна стратегия, но 75\% от фирмите нямат такава и планират действия по отношение на дигитализирането в период от 1 до 5 години. Предприятията в България предприемат стьпки в посока на дигиталните технологии, но повечето от тях се намират в начална фаза на тяхното внедряване. Най-силно внедряваните технологии са мобилните приложения и „Интернет на нещата“ (съответно при 37\% и 34\% от анкетираните), следвани от облачните изчисления (30\%), докато блокчейн технологиите и киберфизичните системи са с много помалък интерес по отношение на потенциалното им внедряване.

Най-голямата пречка за българските предприятия пред внедряването на дигиталните технологии се явява квалификацията на служителите (при 50\% от анкетираните) и размерьт на необходимите инвестиции (при 46,1\% от анкетираните). В допълнение мениджърите се обединяват около необходимостта от по-голяма яснота по отношение на ефектите и процесите на дигитализацията.

Държавата трябва да подпомага бизнеса и да подобрява средата за постигане на повисока производителност, която от своя страна да доведе до по-бързо социалноикономическо развитие. Доклад на глобалната консултантска компания McKinsey посочва, че с преодоляване на дигиталното изоставане от Западна и Северна Европа, България може да увеличи с до 8 млрд. евро брутния си вътрешен продукт до 2025 г. (Digital/McKinsey 2018) Въпреки изоставането, дигиталната икономика в България нараства около два и половина пъти по-бързо, отколкото в 5-те големи пазара на ЕС (Германия, Великобритания, Франция, Италия, Испания) през периода 2013-2017 г. (8,2\% спрямо 3,1\%). Това означава, че България е в добра позиция да се възползва от развиването на дигитализацията, като разчита основно на търговия, тъй като икономиката е по-слабо капитализирана в сравнение с понапредналите западноевропейски държави. България, заедно с останалите страни в региона на Централна и Източна Европа, може да използва дигитализацията като ефективно средство за навлизане в международни вериги за създаване на стойност. Според анализаторите на McKinsey, българският бизнес трябва да ускори приемането на дигитални инструменти, за да увеличи продуктивността и печалбата си, а също така да се възползва от дигиталните решения за изследване на потребителските нагласи и да стъпи на регионални и световни пазари.

\section{3. Тенденции при куриерските услуги}

Постоянното развитие на онлайн търговията изисква усъвършенстване и нарастващо дигитализиране на куриерските услуги, тъй като основният начин, по който се осъществява тази търговия, е чрез изпращане на пощенски и куриерски пратки. В бъдеще модерната търговия ще се базира на интеграцията между онлайн и офлайн магазини, логистика и данни в една-единствена верига на добавената стойност. Ако традиционните търговци не успеят да интегрират новите дигитални технологии в бизнеса си, те ще изгубят пазарните си позиции. От друга страна новите технологии имат голям потенциал за развиване на нови бизнес модели на локално, регионално и глобално ниво. Съвременните потребители разполагат с много голям избор на стоки и услуги, лесно променят поведението и предпочитанията си при пазаруване, което е предпоставка търговците да инвестират най-вече в технологични иновации, чрез които да запазват настоящите си клиенти и да ги превръщат в лоялни. Това обстоятелство изисква генерална промяна и в подхода за осъществяне на куриерските услуги, без които доставките на стоките до клиентите са трудно постижими.

За спечелване доверието на потребителите особено важна се оказва високоскоростната доставка. Нова технология, която променя конфигурацията на веригата за доставки е триизерният или т.нар. 3D печат. Тази технология е разработена за създаване на триизмерни прототипи от различни материали: пластмаса, керамика, метал, чрез използване 
на дигитални модели, от които слой по слой се принтират триизмерни продукти. По този начин се създава възможност за производство на продукти с минимално човешко участие. Принтираните продукти могат да бъдат създадени точно според желанията на потребителите, които имат свободата да поръчват промени в дизайна, цвета и формата на стоките спрямо индивидуалните си предпочитания. Най-голямото предимство е бързината на доставката. Използвайки 3D технологията, логистичните компании могат да играят ролята на производители. Не е необходимо стоката да се чака, дори ако производителят/търговецът се намира в другия край на света. Достатъчно е само стоката да бъде поръчана, след което тя ще бъде принтирана точно според желанията на клиента и то на разстояние, което е много близо до него. Така производството се премества възможно най-близо до крайния пазар, следствие на което разходите по веригата на доставките се намаляват неколкократно. Отпада необходимостта търговецът да поддържа големи количества стокови запаси на склад, за да задоволява бързо потребителското търсене. Не са необходими и скъпоструващи проучвания на потребителското поведение, тъй като може да се произведе всичко, което потребителят пожелае. Вместо да поддържат излишни стокови запаси, производителите и тьрговците могат да създават виртуален склад, в който се съхраняват файлове за бързо отпечатване на стоките при поискване от потребителите. За да се осигури бърза доставка на поръчаните стоки от клиентите, производственият процес може да се прехвърли директно към доставчиците на логистични услуги. Куриерските фирми имат потенциал да постигнат икономии от мащаба на дейността си чрез изграждането на мрежа от споделени 3D принтери, разположени в дистрибуционните им центрове по целия свят. При възникване на потребност от стоката, потребителите ще изпращат поръчка до най-близкия до тях 3D принтер, а организирането на производствения процес възможно най-близо до крайните потребители ще намали съществено разходите по веригата за доставки. 3D принтирането е своеобразна революция в технологиите на производство, позволяваща автоматизация в условията на значително намаляване на разходите. Тъй като триизмерните принтери са в състояние да произвеждат и дребни части за сглобяване, които могат да бъдат променяни във всеки момент, съобразно желанията на клиента, ще може да бъде премахната разликата при ценообразуването на серийното производство и единичното изделие. Благодарение на 3D принтиращата технология повече стоки ще могат да се произвеждат на локално ниво, което ще доведе до значително по-ниски транспортни разходи. Крайните клиенти ще бъдат доволни, поради възможността да закупят продукта с по-ниска себестойност и бързина на доставката. Ползи ще има и за околната среда от намаленото количество на превозите и изгорелите газове в атмосферата.

Изкуственият интелект постепенно започва да навлиза в логистичната индустрия и в частност при куриерските услуги в посока на автоматизация на процесите и нови модели за работа с клиентите. Той поставя началото на т. нар. интелигентна логистика и позволява логистичните операции да станат проактивни и предвидими. Благодарение на изкуствения интелект логистичните компании ще могат да доставят стоки още преди клиентьт да ги е поръчал. Така например изкуственият интелект може да прогнозира търсенето, като използва данни от онлайн магазини и потребителски форуми, за да предскаже неочаквани увеличения в обема на трендови продукти. Използването на разговорни автоматизирани интелигентни интерфейси при обслужването на клиентите ще даде възможност на доставчиците на куриерски услуги да оптимизират взаимодействието си с клиентите и да персонализират в по-голяма степен услугите с конкретните нужди и предпочитания. С гласова услуга за проследяване на пратки и интелигентен високоговорител клиентите на куриерските фирми ще могат да получават информация в реално време за тяхната доставка, включително къде се намира пратката в момента, кой е номера на полета или кораба, с който пратката ще се 
транспортира и кога се очаква да пристигане. Гласовото проследяване може да бъде интегрирано във виртуалните асистенти, базирани на изкуствения интелект, като „Siri“, „Aleха““ и др. и това да подобри още повече потребителските преживявания при онлайн пазаруването.

Интелигентни очила за работа със свободни ръце, използващи технологията добавена реалност (AR), могат да облекчат редица задачи, изпълнявани в логистичния склад, като събиране; опаковане; сортиране и дори сглобяване на стоки. Куриерите, оборудвани с интелигентни очила, имат възможност да извършват проверки за пълнота на всяка пратка, използвайки технология за разпознаване на обекти. Добавената реалност може сьщо да се използва за визуализиране на вътрешността на превозното средство, за да се покаже правилната последователност на натоварване на пратките, като се вземе предвид тяхното тегло, крехкост, маршрут на придвижване и т.н. AR може да помогне и при доставката в „последната миля“44, когато куриерите търсят конкретен офис или входна врата. Очилата с добавена реалност могат да ги насочват във вътрешността на сградата и да им показват необходимите входове, както и да дават съвети по време на навигацията.

Технологиите за бионично подобрение имат потенциала да разширят настоящите физически граници и да сведат до минимум рисковете за здравето, особено на повъзрастните логистични работници, при изпълнение на товаро-разтоварните процеси. Екзоскелетите са роботизирани костюми, които повишават силата и издръжливостта на носещия ги работник, като значително намаляват физическото натоварване върху мускулите и костите при ръчните дейности. Това помага да се повиши производителността и безопасността на труда, както и намаляване на умората. Чрез тях биха могли да се заменят обемисти инструменти за повдигане на тежки предмети. Внедрените в експлоатация към момента екзоскелети са механизми, които се закрепят на гърба на работника и подкрепят долната част на тялото при вдигане и носене на предмети. Използва се система от пружини, служеща като обратна тяга, която дава опора при навеждане и по този начин усилията на работника се намаляват наполовина. Този тип екзоскелет е пасивен и следи движението на работника, редуцирайки усилието му при вдигане на товари. Работи се и по създаването на активен екзоскелет, който да подкрепя ръцете на работниците. При куриерските услуги бионичните технологии ще са много полезни при доставката на тежки мебели и обемисти битови електроуреди в дома на купувачите.

С технологичния напредък в изкуствения интелект и инвестициите в разработването на сензори и визуални технологии, се очаква технологиите за автономно управление да осигурят по-точни и по-надеждни доставки на стоковите пратки, като същевременно намалят разходите. Автономната технология бележи голям напредък през последните години в затворените помещения на логистичната индустрия. В логистичните складове с помощта на самоходни превозни средства се постигна значително по-висока производителност и безопасност на труда при изпълнение поръчките на клиентите. Автомобилите със самостоятелно управление скоро ще оптимизират транспортните операции и ще повишат безопасността на движението. Внедряването на множество безпилотни превозни средства при транспортирането на стоките в открити пространства е от съществено значение за процеса на дигитализация във веригата на доставките. Умните автономни превозни средства ще се справят с редица проблеми, като непълен превозен капацитет и загуба на време в задръствания. Самоуправляващите се превозни средства използват картографиращи сензори и позициониращи радари, за да преработват постьпващата информация от околната среда и

\footnotetext{
${ }^{4}$ Под „последна миля“ се разбира последната отсечка от веригата за доставка на стоки, включваща пьтя от транспортния центьр до крайния клиент.
} 
да осигуряват по-бързо, евтино и безопасно изпълнение на доставките. Тези превозни средства имат по-висока ефективност, тъй като позволяват 24-часов режим на работа без необходимост от почивка, поради липсата на водач и постигат ускоряване на трафика чрез програмирано избягване на пътните задръствания. В допълнение автономната технология може значително да намали броя на злополуките и пътнотранспортните произшествия при доставката на стоки на далечни разстояния, тъй като изчислява безопасността на всяка маневра и по този начин намалява грешките на водачите на превозните средства.

За преодоляване на основния недостатък за потребителите при онлайн пазаруването чакането в дни за получаване на закупените стоки, ускорено се разработват летящи роботи куриери или дронове, които да доставят поръчките в рамките на часове. Към настоящия момент повечето проекти са още в тестови период, но бъдещото масово въвеждане на куриерските роботи е сигурно, поради безспорните им предимства. Тези предимства са не само по отношение бързината на доставката, но и в значителното намаляване на разходите за доставка, тъй като роботите се движат с батерии и не предизвикват замърсяване на въздуха, което е неизбежно при автомобилните доставки в урбанизираните територии. Безпилотните летателни апарати могат да се използват за доставяне на стоки в „последната миля“, както и за операции в областта на вътрешната логистика и наблюдение. Оборудвани с технология за компютърно зрение, те могат да се позиционират в логистичните складовете за извършване на инвентаризационни проверки, като по този начин ще осигуряват по-висока прозрачност на наличните запаси и предотвратяване на кражби. Дроновете за доставка няма да заменят традиционния наземен транспорт, но ще са особено полезни за осигуряване на доставки в отдалечени, потенциално опасни за достъп места. Те имат потенциала да променят начина, по който стоките се доставят в мегаполисите и отдалечените селски райони. Доставките в „последната миля“, използващи безпилотни летателни апарати, позволяват да се намалят сроковете за доставка, като се преодолеят задръстванията в гъсто населените градове. В селските райони с трудна достьпност също могат да се изпращат безпилотни летателни апарати и така да се осигуряват превози при поискване по въздух, дори при опасни условия.

Услуга, която набира все по-голяма популярност при онлайн пазаруването и се разработва от куриерските фирми е т.нар. „click and collect”5 опция. С тази опция потребителите имат възможност да закупуват онлайн стоки от различни търговци, след което порьчаните стоки се обединяват в една доставка и се транспортират до предварително избрано, удобно за тях място, от където да ги вземат самостоятелно. Услугата „click and collect” позволява на потребителите да избегнат загубата на време в очакване на куриер и допълнителните такси за доставка. Към момента предизвикателство пред куриерските фирми е доставянето на поръчаните от потребителите стоки в рамките на деня на поръчката, като очакванията на потребителите са в бъдеще това да става дори само в рамките на час-два.

Разпространението на интелигентни домове позволя нови модели за доставка, базирани на концепцията за „Интернет на нещата“ (IoT), като например услуги за доставка на стоки в дома на клиента. Посредством използването на интелигентни брави много скоро куриерите ще могат да получават дистанционен ключ за дома на клиента, за да бъде доставена пратката в самия дом, а не пред вратата или в пощата. Сигурността на операцията ще се гарантира от камера, която ще прави запис от момента на отваряне на вратата. Собствениците на жилището ще се известяват за доставката от специално мобилно приложение и ще могат да преглеждат записа от камерата.

Друга услуга с голям потенциал за развитие от куриерските фирми е директната доставка на поръчаните онлайн стоки до автомобила на клиента. По този начин се избягва

\footnotetext{
${ }^{5}$ Може да се преведе като „направи онлайн порьчка и я получи на избрано място“.
} 
пропускането на доставка от клиента и изминаването на разстояние до офис на куриерската фирма за получаване на стоките, което коства допълнителни разходи и време за потребителите. Услугата е възможна посредством временно разрешение за безключов достьп на куриера до багажника на автомобила. В момента на доставката куриерьт получава цифров код на преносимо безжично устройство, което отваря багажника на автомобила и след оставяне на стоката и затваряне на багажника, кодът за достъп се деактивира. В бъдеще куриерските фирми ще разработват и възможността за изпращане на колети или връщане на стоки от багажника на автомобила, което още повече ще улесни потребителите на омниканалната търговия.

Куриерските фирми се насочват и към предлагане на възможност за самообслужване от клиентите с помощта на свързани към интернет автоматични пощенски станции, които приемат колети. Така клиентите могат да изпращат и получават пратки сами по всяко време на денонощието, без да се нуждаят от пряк контакт със служител на куриерската компания и без да се съобразяват с нейното работно време. Други предимства за клиентите се изразяват в цената на услугата, която при самообслужване е по-ниска от стандартната куриерска услуга, както в ползването на отстьпка, ако пратката е от и до една и съща автоматична пощенска станция. Очакванията са автоматичните станции да се наложат в бъдеще като стандарт при куриерските услуги, заради удобствата, които предлагат както на клиентите, така и на търговските фирми.

В куриерския бизнес постепенно навлизат и технологични иновации, като анализа на големи данни, предлагащ огромен потенциал за оптимизиране използването на наличния капацитет; блокчейн технологията, създаваща по-голямо доверие и прозрачност между заинтересованите страни по веригата за доставки и облачните услуги, които дават възможност за бърз и гъвкав достъп до ИТ услуги, без да се изискват големи разходи за разработка и поддръжка на собствена ИТ инфраструктура.

\section{Заключение}

Дигитализацията на търговията променя търговския сектор, като създава нови бизнес модели и възможности за извършване на бизнеса, нови форми на взаимодействие с потребителите и начини за задоволяване на техните изисквания. В епохата на глобална обвързаност, научни достижения в областта на технологиите и постоянно нарастваща конкуренция, потребителите търсят не просто стоки и услуги, а комбинация от иновативни предложения, улесняващи и разнообразяващи техния живот. Необходимото участие на куриерските компании във веригата на доставките налага непрекъснато адаптиране към променящите се изисквания на потребителите и внедряване на ново високотехнологично ниво на взаимодействие с тях. Дигиталните иновации предоставят възможности за осъществяване на куриерските услуги с по-ниски разходи, по-ефективна верига за доставки и персонализирано клиентско обслужване. В допълнение е налице и положително въздействие върху околната среда чрез намаляване на въглеродните емисии от товарния транспорт.

\section{References}

1. AHK Bulgarien (2018) Prouchvane za nivoto na digitalizatsia v Bulgaria. [Online] Available from: https://bulgarien.ahk.de/fileadmin/AHK_Bulgarien/News/Digitalization_Survey_Bulgaria -BG.pdf [Accessed 13/10/2019].

2. Bulgarian Industrial Association (2018) Strategy Industry 4.0. [Online] Available from: https://www.bia-bg.com/uploads/files/events/Industry_4.0/Strategy_Industry\%204.0_draft_30\% 20March\%202018.pdf [Accessed 02/10/2019].

3. Digital/McKinsey (2018) The rise of Digital Challengers. How digitalization can become the 
next growth engine for Central and Eastern Europe. [Online] Available from: https://digitalchallengers.mckinsey.com/files/McKinsey\%20CEE\%20report_The\%20Rise\%20of \%20Digital\%20Challengers.pdf [Accessed 29/09/2019].

4. European Commission (2019) Indeks za navlizaneto na tsifrovite tehnologii v ikonomikata $i$ obshtestvoto (DESI) za 2018 g. [Online] Available from: http://ec.europa.eu/information society/newsroom/image/document/2018-20/bg-desi_2018-country-profile-lang_4AA75D95A1C8-8688-2FEE98B6EE01186C52355.pdf/ [Accessed 10/10/2019].

5. European Commission (2019) Digital Single Market Report. [Online] Available from: https://ec.europa.eu/digital-single-market/en/news/international-digital-economy-and-societyindex-2018 [Accessed 10/10/2019].

6. European Ecommerce (2019) European Ecommerce Report. [Online] Available from: https://www.ecommercewiki.org/reports/792/european-ecommerce-report-2019-free [Accessed 15/10/2019].

7. European Ecommerce (2018) European Ecommerce Report. [Online] Available from: https://www.haendlerbund.de/de/downloads/ecommerce-europe/european-ecommerce-report2018.pdf [Accessed 15/10/2019].

8. Lazar, M.-J. (2019) Facts About Shopping Cart Abandonment Rates. [Online] Available from: https://www.readycloud.com/info/use-these-facts-about-shopping-cart-abandonment-rates-tobeat-the-odds [Accessed 08/10/2019].

9. Ministerstvo na ikonomikata (2017) Kontseptsia Industria 4.0. [Online] Available from: https://www.mi.government.bg/files/useruploads/files/ip/kontseptsia_industria_4.0.pdf [Accessed 03/10/2019].

10. Ministerstvo na obrazovanieto i naukata (2014) Strategia efektivno IKT. [Online] Available from: http://mon.bg/upload/6543/strategia_efektivno_ikt_2014_2020.pdf [Accessed 01/10/2019].

11. Ministerstvo na obrazovanieto i naukata (2014) Plan strategia IKT [Online] Available from: http://mon.bg/upload/6544/2015_Plan_Strategia_IKT_vnedrjavane.pdf [Accessed 01/10/2019].

12. Ministerstvo na transporta, informatsionnite tehnologii i saobshteniyata (2014) Strategia za razvitie na EU. [Online] Available from: https://www.mtitc.government.bg/archive/upload/ docs/2014-03/1_StrategiaRazvitieEU_RBulgaria_2014_2020.pdf [Accessed 02/10/2019].

13. Ministerstvo na transporta, informatsionnite tehnologii i saobshteniyata (2012) Aktualizirana strategia. [Online] Available from: https://www.mtitc.government.bg/upload/docs/ AktualiziranaStrategia.pdf [Accessed 02/10/2019]. 